\title{
Religion, Ethnicity and Identity in Ancient Galilee
}

\author{
A Region in Transition \\ Ed. by Jürgen K. Zangenberg, Harold W. Attridge, and Dale B. Martin
}

[Religion, Ethnizität und Identität im antiken Galiläa. Eine Region im Umbruch.]

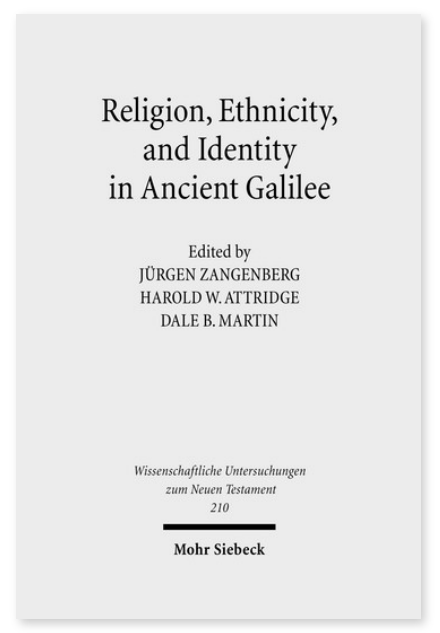

2007. XV, 509 Seiten. WUNT I 210

SBN 978-3-16-151499-9

DOI 10.1628/978-3-16-151499-9

eBook PDF $154,00 €$

ISBN 978-3-16-149044-6

Leinen $154,00 €$
Veröffentlicht auf Englisch.

Wer galt als 'Galiläer' und warum? Welche Kriterien werden in der Antike für diese Zuschreibung benutzt und was können archäologischen Quellen zur Klärung beitragen? Welche Bedeutung besaß Religion in diesem Gemenge? Die Autoren der 22 Artikel des Bandes greifen die neuesten Erkenntnisse aus Bibelwissenschaft, Archäologie, Rabbinic Studies, Numismatik, Epigrafik, Musik- und Literaturwissenschaft auf und leisten so einen wichtigen Beitrag nicht nur zur Erhellung des sozial- und kulturgeschichtlichen Hintergrunds der galiläischen Jesusbewegung und des entstehenden rabbinischen Judentums, sondern sie beleuchten zugleich das komplexe Wechselspiel zwischen indigenen Kulturen mit ihren Institutionen und Selbstdefinitionen sowie hellenistisch-römischem Einfluss im östlichen Mittelmeerbereich. Es zeigt sich, dass Galiläa seine Geheimnisse besonders dann zu entlocken sind, wenn man es als dynamische Region versteht, in der Ethnizität und Identität ihre Konturen in konstanter Bewegung und Gegenbewegung ausgebildet haben.

Inhaltsübersicht

Content:

Jürgen Zangenberg: A Region in Transition. Introducing Religion, Ethnicity, and Identity in Ancient Galilee

I. The State of Affairs in Galilean Studies

Sean Freyne: Galilean Studies. Old Issues and New Questions

II. »What is a Galilean«? Modes of Defining Religion, Ethnicity and Identity in Textual and Archaeological Sources

Martin Karrer: Licht über dem Galiläa der Völker. Die Fortschreibung von Jes 9:1-2 in der LXX - Timothy Luckritz Marquis: RePresenting Galilean Identity. Josephus' Use of 1 Maccabees 10:25-45 and the Term Ioudaios - Silvia Cappelletti: Non-Jewish Authors on Galilee - Mark A. Chancey: The Epigraphic Habit of Hellenistic and Roman Galilee - Michael Peppard: Personal Names and Ethnic Hybridity in Late Ancient Galilee. The Data From Beth She'arim - Mordechai Aviam: Distribution Maps of Archaeological Data from the Galilee. An Attempt to Establish Zones Indicative of Ethnicity and Religious Affiliation - Milton Moreland: The Inhabitants of Galilee in the Hellenistic and Early Roman Periods. Probes into the Archaeological and Literary Evidence

III. Identity at Ground Level: New Evidence from Sites and Regions of Galilee

Wolfgang Zwickel: The Huleh Valley from the Iron Age to the Muslim Period. A Study in Settlement History - Carl Savage: Supporting Evidence for a First-Century Bethsaida - Yizhar Hirschfeld and Katharina Galor: New Excavations in Roman, Byzantine, and Early Islamic Tiberias - Anders Runesson: Architecture, Conflict, and Identity Formation. Jews and Christians in Capernaum From the 1st to the 6th Century - Jodi Magness: Did Galilee Decline in the Fifth Century? The Synagogue at Chorazin Reconsidered

IV. »A Region of Many Identities«. Cultural Interaction and Social Relations in and with Ancient Galilee

Morten Hørning Jensen: Message and Minting. The Coins of Herod Antipas and Their Second Temple Context as a Source for Understanding the Religio-Political and Socio-Economical Dynamics of Early First Century Galilee - Marcus Sigismund: Small Change? Coins and Weights as a Mirror of Ethnic, Religious and Political Identity in 1st /2nd Century C.E. Tiberias - Monika Bernett: Roman Imperial Cult in the Galilee. Structures, Functions, and Dynamics - Douglas R. Edwards: Identity and Social Location in Roman Galilean Villages - Stuart S. Miller: Priests, Purities, and the Jews of the Galilee - Joshua Ezra Burns: The Archaeology of Rabbinic Literature and the Study of Jewish-Christian Relations in Late Antiquity. A Methodological Evaluation Mira Waner: Music Culture in Ancient Sepphoris - Thomas M. Weber: Gadara and the Galilee

Jürgen K. Zangenberg Studium der evangelischen Theologie in Erlangen, Heidelberg und Edinburgh; Promotion zum Dr. theol. 1996 an der Ruprecht-Karls-Universität Heidelberg; 2003 Habilitation an der Kirchlichen Hochschule und der Bergischen Universität Wuppertal; seit 2006 Professor für Neues Testament und Frühchristliche Literatur sowie seit 2008 auch an der Fakultät für Archäologie der Universität Leiden/Niederlande. https://orcid.org/0000-0001-7894-3605

Harold W. Attridge Born 1946; 1967 A.B. Boston College; 1969 B.A. Cambridge University; 1975 PhD Harvard University; currently Sterling Professor of Divinity, Yale Divinity School.

Dale B. Martin Keine aktuellen Daten verfügbar. 
Jetzt bestellen:

https://mohrsiebeck.com/buch/religion-ethnicity-and-identity-in-ancient-galilee-9783161514999?no_cache=1

order@mohrsiebeck.com

Telefon: +49 (0)7071-923-17

Telefax: $+49(0) 7071-51104$ 